\title{
Peningkatan Kinerja Angkutan Kota di Kota Kupang dalam Kerangka Balanced Scorecard
}

\author{
Pipit Rusmandani, Shalma Nur Fauzia \\ Sekolah Tinggi Transportasi Darat-Politeknik Transportasi Darat Indonesia \\ Email: Pipit@pktj.ac.id
}

\begin{abstract}
Abstrak
Fenomena meningkatnya penggunaan kendaraan pribadi dan semakin menurun minat masyarakat menggunakan moda transportasi umum telah menjadi permasalahan utama yang dihadapi di daerah perkotaan, hal ini juga terjadi di Kota Kupang terbukti dari 991.416 perjalanan/hari hanya 3\% saja yang menjadikan angkutan umum sebagai moda transportasi. Oleh sebab itu penelitian ini bertujuan untuk mengetahui Peningkatan Kinerja Angkutan Kota di Kota Kupang dalam Kerangka Balanced Scorecard. Penelitian ini menggunakan pendekatan kuantitatif dengan teknik pengukuran kinerja menggunakan balanced scorecard. Hasil analisis kinerja angkutan kota di Kota Kupang dengan menggunakan metode Balanced Scorecard memberikan gambaran aspek angkutan kota yang bermasalah dari tiap perspektif yang dari segi nilai masuk kedalam prioritas perbaikan, yaitu: Retensi pelanggan pada perspektif pelanggan; Tingkat laba pada perspektif keuangan; Retensi pekerja pada perspektif pertumbuhan dan pembelajaran
\end{abstract}

Kata Kunci : Angkutan Kota, Kendaraan Pribadi, Kinerja, Balanced Scorecard.

\begin{abstract}
The phenomenon of increasing use of private vehicles and decreasing public interest in using public transportation has become the main problem faced in urban areas, this also occurs in Kupang City as evidenced by 991,416 trips/day only 3\% of which make public transportation a mode of transportation. Therefore, this study aims to determine the Improvement of City Transportation Performance in Kupang City in the Balanced Scorecard Framework. This study uses a quantitative approach with performance measurement techniques using a balanced scorecard. The results of the analysis of the performance of urban transportation in Kupang City using the Balanced Scorecard method provide an overview of the problematic aspects of city transportation from each perspective which in terms of value is included in the priority of improvement, namely: Customer retention from the customer perspective; Profit rate from a financial perspective; Employee retention on a growth and learning perspective
\end{abstract}

Keywords: City Transportation, Private Vehicles, Performance, Balanced Scorecard 


\section{A. PENDAHULUAN}

Kota Kupang merupakan ibu kota Provinsi Nusa Tenggara Timur dengan jumlah penduduk tahun 2018 sebesar 423.800 jiwa dengan jumlah keluarga 100.352 keluarga. Dengan jumlah tersebut dan trip rate sebesar 2,9 (Laporan Umum Tim Praktek Kerja Lapangan Kota Kupang Tahun 2019) maka rata-rata terdapat 1.229.020 perjalanan setiap harinya. Aktivitas pergerakan ini mutlak memerlukan sarana dan prasarana transportasi yang memadai baik secara kualitas maupun kuantitas.

Fenomena motorisasi dan meningkatnya penggunaan kendaraan pribadi merupakan permasalahan yang dapat menurunkan kinerja pelayanan angkutan umum. Berlaku sebaliknya, kinerja pelayanan angkutan umum yang buruk dapat memicu hilangnya minat masyarakat dalam menggunakan angkutan umum sehingga penggunaan kendaraan pribadi meningkat, keduanya dapat menimbulkan permasalahan transportasi di masa yang akan datang.

Angkutan pada dasarnya adalah sarana untuk memindahkan orang dan atau barang dari satu tempat ke tempat lain. Tujuannya membantu orang atau kelompok orang menjangkau berbagai tempat yang dikehendaki atau mengirimkan barang dari tempat asalnya ke tempat tujuannya. Prosesnya dapat dilakukan dengan menggunakan sarana angkutan berupa kendaraan. Sementara angkutan umum penumpang adalah angkutan penumpang yang menggunakan kendaraan umum yang dilakukan dengan sistem sewa atau bayar. Termasuk dalam pengertian angkutan umum penumpang adalah angkutan kota (bus, minibus, dsb), kereta api, angkutan air, dan angkutan udara. (Warpani, 1990).

Kondisi eksisting menunjukkan adanya permasalahan pada pelayanan angkutan umum perkotaan di Kota Kupang, baik dari sudut pandang penumpang, operator, maupun pemerintah. Keadaan tersebut dapat berdampak pada pengguna angkutan umum golongan captive saja atau pengguna yang tidak memiliki alternatif moda transportasi lain dan belum mampu menarik masyarakat yang memiliki kendaraan pribadi untuk berpindah moda transportasi. Angkutan umum harus diminati masyarakat dan menjadi moda utama bagi masyarakat untuk bertransportasi agar kedepannya tercipta ruang lalu lintas yang tertib dan lancar. Hal ini terbukti dari 991.416 perjalanan/hari hanya 3\% saja yang menjadikan angkutan umum sebagai moda transportasi. Berdasarkan Laporan Umum Tim PKL Kota Kupang tahun 2019 proporsi penggunaan moda transportasi di Kota Kupang didominasi dengan kendaraan pribadi terutama sepeda motor yaitu sebesar $78 \%$ disusul dengan mobil sebesar 17\%. Selain itu, perbandingan jumlah penumpang terangkut harian rata-rata pada tahun 2019 dengan jumlah penumpang terangkut harian rata-rata pada tahun 2009 menunjukan penurunan yang cukup signifikan hal ini sejalan dengan berkurangnya jumlah armada yang beroperasi. Hal ini dapat menandakan bahwa angkutan umum kurang diminati, meski saat ini tidak terdapat masalah transportasi yang berarti namun bukan tidak mungkin pada masa yang akan datang lalu lintas di Kota Kupang menjadi tidak terkendali akibat arus yang melewati jalan telah melampaui kapasitas jalan sehingga tingkat kemacetan tinggi.

Menanggapi hal tersebut dan demi terbentuknya suatu sistem transportasi yang berkelanjutan, perlu persiapan yang baik dalam penataan dan sistem terpadu, maka diperlukan suatu kajian sebagai dasar evaluasi dan pengembangan untuk mengidentifikasi permasalahan guna mendapatkan alasan mengapa saat ini angkutan kota di Kota Kupang kurang diminati, serta akibat yang disebabkan oleh kurangnya minat tersebut. Oleh karenanya evaluasi maupun perbaikan, perencanaan, dan peningkatan kualitas pelayanan atau jasa menjadi sangat penting dilakukan jika perusahaan, dalam hal ini perusahaan angkutan kota ingin tetap beroperasi dan tetap menghasilkan keuntungan. 
Berdasarkan latar belakang dan uraian di atas maka penelitian ini ditujukan untuk menganalisis kinerja angkutan kota dengan menggunakan pendekatan suatu metode yang dapat mengintegrasikan berbagai ukuran yang diturunkan dari strategi operator serta pemecahan masalah dalam hasil analisa peningkatan kinerja pelayanan menjadi dasar untuk dilakukannya penelitian mengenai "Peningkatan Kinerja Angkutan Kota Di Kota Kupang Dalam Kerangka Balanced Scorecard".

\section{B. METODE}

Penelitian ini menggunakan pendekatan kuantitatif. Dalam pendekatan kuantitatif, dilakukan perhitungan-perhitungan yang relevan dengan permasalahan yang diteliti. Teknik pengukuran kinerja menggunakan Balanced Scorecard yang ditinjau dari perspektif pelanggan dilakukan dengan penyebaran kuesioner kepada responden sehingga semua instrumen penelitian yang digunakan harus diuji terlebih dahulu untuk mengetahui apakah instrumen tersebut valid dan reliabel. Pengujian instrumen dilakukan dengan menggunakan Uji Validitas.

\section{HASIL DAN PEMBAHASAN}

\section{Penilaian Kinerja Angkutan Kota Menggunakan Metode Balanced Scorecard}

a. Retensi Pelanggan

Indikator ini menunjukan kemampuan angkutan kota dalam mempertahankan hubungan dengan para pelanggannya atau dalam hal ini adalah pengguna jasa angkutan kota. Dari hasil penelitian menunjukkan bahwa realisasi penumpang terangkut harian rata-rata belum mencapai target, dari target sebesar 101.992 penumpang/hari kondisi eksisting hanya melayani sebesar 26.270 penumpang/hari yang artinya angkutan kota di Kota Kupang tidak mampu mempertahankan jumlah penumpang maupun mengakuisisi penumpang.

\section{b. Tingkat Komplain Pelanggan}

Jumlah komplain merupakan indikator yang digunakan untuk mengetahui seberapa besar jumlah pelanggan yang melakukan komplain dibandingkan jumlah keseluruhan pelanggan yang menggunakan angkutan kota. Komplain tersebut tidak dipersepsikan sebagai sesuatu yang negatif, tetapi sebagai bentuk perhatian dan saran dari pelanggan. Karena belum tersedianya platform resmi untuk menampung aspirasi pelanggan, komplain terkumpul dari wawancara pengguna angkutan kota serta kuesioner kepuasan pengguna angkutan kota. Dari hasil penelitian dapat diketahui bahwa dari jumlah penumpang tahun 2019 yang berjumlah 26.270 penumpang terdapat 676 komplain atas pelayanan angkutan kota.

\section{c. Kepuasan Pelanggan}

Sebelum dilakukan interpretasi data yang didapat dari eksplorasi tiap variabel kepuasan pelanggan melalui item-item pernyataan yang telah disusun, dilakukan pengujian validitas dan reliabilitas untuk mengetahui apakah item-item pertanyaan yang digunakan dalam kuesioner valid, dalam arti dapat digunakan sebagai instrumen penelitian, dan reliabel, dalam artian item-item pertanyaan dapat dipercaya dan diandalkan. Setiap item pertanyaan dapat dikatakan valid apabila hasil korelasi Pearson menunjukkan nilai diatas nilai yang ditentukan distribusi rtabel 0,05 (5\%), dan sebaliknya dinyatakan tidak valid. Sedangkan seluruh item pertanyaan dikatakan reliabel apabila hasil perhitungan Cronbach's Alpha menunjukan nilai diatas 0.60 (Sujarweni, 2014).

Dari hasil pengukuran diketahui bahwa dari setiap item pertanyaan yang dikelompokkan kedalam 5 faktor yaitu Faktor Bukti Fisik (Tangibles), Kehandalan (Reliability), Daya Tanggap (Responsiveness), Jaminan (Assurance), dan Empati (Emphaty) seluruhnya memiliki nilai diatas 0,113 dan dinyatakan valid. Sementara hasil perhitungan menggunakan rumus Cronbach's Alpha 
dan didapatkan hasil 0,170, nilai tersebut lebih besar dari 0,60 (Wiratna Sujarweni, 2014). Maka dari itu dinyatakan bahwa seluruh item pertanyaan reliabel dan dapat diandalkan sebagai instrumen penelitian.

1) Analisis Tolok Ukur Perspektif Keuangan

Pengukuran perspektif keuangan dilakukan dengan menghitung tingkat pengeluaran operator tahun (n) yang selanjutnya dibandingkan dengan tingkat pendapatan operator tahun (n) untuk mengetahui persentase tingkat laba operator. Tingkat pendapatan didapatkan dari jumlah penumpang terangkut/tahun dikalikan dengan tarif yang berlaku.

Tabel 1 Penerapan Tarif Angkutan Kota di Kota Kupang

\begin{tabular}{|c|c|c|c|c|}
\hline \multirow{2}{*}{$\begin{array}{c}\text { Kode } \\
\text { Trayek }\end{array}$} & Pendapatan/tahun & $\begin{array}{l}\text { Pengeluaran } \\
\text { (BOK/tahun) }\end{array}$ & Pendapatan Bersih & \multirow{2}{*}{$(\mathrm{c}) /(\mathrm{a})$} \\
\hline & (a) & (b) & (c) & \\
\hline 1 & Rp. 2,113,350,000 & Rp. 1,533,446,054 & Rp. 579,903,945 & $27.4 \%$ \\
\hline 2 & Rp. $4,078,875,000$ & Rp. 3,783,626,475 & Rp. 295,248,524 & $7.2 \%$ \\
\hline 3 & Rp. $2,347,680,000$ & Rp. $2,554,769,948$ & Rp. $-207,089,948$ & $-8.8 \%$ \\
\hline 5 & Rp. 2,677,275,000 & Rp. 2,266,299,517 & Rp. $410,975,482$ & $15.4 \%$ \\
\hline 6 & Rp. $7,010,190,000$ & Rp. 5,169,759,002 & Rp. $1,840,430,997$ & $26.3 \%$ \\
\hline 7 & Rp. $3,725,190,000$ & Rp. 4,315,866,739 & Rp. $-590,676,739$ & $-15.9 \%$ \\
\hline 10 & Rp. $3,600,360,000$ & Rp. $3,729,568,050$ & Rp. $-129,208,050$ & $-3.6 \%$ \\
\hline 27 & Rp. $3,212,730,000$ & Rp. 2,804,612,165 & Rp. $408,117,834$ & $12.7 \%$ \\
\hline $\begin{array}{l}\text { Rata- } \\
\text { rata }\end{array}$ & Rp. 3,595,706,250 & Rp. 3,269,743,494 & Rp. $325,962,755$ & $8 \%$ \\
\hline
\end{tabular}

Dapat diketahui dari Tabel V.32 diatas bahwa tiga trayek belum mampu menutupi biaya operasional kendaraan yaitu trayek 3, trayek 7, dan trayek 10. Namun, meskipun trayek lain mampu menutupi biaya operasional kendaraan operator memiliki laba yang tidak terlalu menguntungkan.

2) Analisis Tolok Ukur Perspektif Proses Bisnis Internal

- Tingkat Operasional Armada

Salah satu tolok ukur untuk menghitung perspektif proses bisnis internal adalah tingkat operasi armada yang didapatkan dari membandingkan jumlah armada yang beroperasi dengan jumlah armada yang diizinkan oleh pemerintah.

Tabel 2 Tingkat Operasi Armada Angkutan Kota di Kota Kupang Tahun 2019 


\begin{tabular}{|c|c|c|c|}
\hline No. Trayek & Izin Armada & $\begin{array}{c}\text { Armada } \\
\text { Beroperasi }\end{array}$ & Tingkat Operasi \\
\hline 1 & 15 & 10 & $66.67 \%$ \\
\hline 2 & 53 & 25 & $47.17 \%$ \\
\hline 3 & 26 & 16 & $61.54 \%$ \\
\hline 5 & 16 & 15 & $93.75 \%$ \\
\hline 6 & 74 & 33 & $44.59 \%$ \\
\hline 7 & 34 & 27 & $79.41 \%$ \\
\hline 10 & 26 & 24 & $92.31 \%$ \\
\hline 27 & 30 & 18 & $60.00 \%$ \\
\hline \multicolumn{3}{|c|}{ Rata-rata } & $68.18 \%$ \\
\hline
\end{tabular}

Dari Tabel 2 diatas dapat diketahui bahwa tidak ada trayek yang beroperasi sesuai dengan jumlah yang diizinkan, hal ini dapat berarti keaadaan dilapangan tidak terlalu menguntungkan bagi operator jika armada yang beroperasi terlalu banyak, perlu adanya kajian lebih lanjut mengenai kebutuhan armada angkutan kota yang beroperasi sesuai dengan demand pergerakan masyarakat agar kedua belah pihak diuntungkan.

- Kecelakaan Armada

Yaitu tolok ukur yang digunakan untuk melihat berapa kecelakaan yang terjadi di sepanjang trayek angkutan kota yang melibatkan arrmada angkutan kota. Data yang diukur adalah data kecelakaan yang terjadi pada tahun 2019 dibagi dengan $\mathrm{km}$ tempuh dalam setahun dibandingkan dengan target yang telah ditetapkan.

Dari hasil penelitian dapat diketahui bahwa terdapat 32 kecelakaan lalu lintas yang melibatkan angkutan kota, berdasarkan hasil perbandingan jumlah kejadian dengan $\mathrm{km}$ tempuh angkutan kota dalam setahun didapatkan persentase tingkat kecelakaan armada angkutan kota pada tahun 2019 sebesar $0,08 \%$.

3) Analisis Tolok Ukur Perspektif Pertumbuhan dan Pembelajaran

- Retensi Pekerja

Retensi pekerja adalah kemampuan operator untuk mempertahankan pekerjanya yang juga dapat diartikan bahwa kegiatan pelayanan jasa menunjukkan hasil yang memuaskan. Satu pekerja diasumsikan memegang satu armada untuk satu hari operasi. Retensi pekerja dihitung berdasarkan perbandingan jumlah pekerja tahun 2019 dengan jumlah pekerja tahun 2009 seperti pada Tabel 3 dibawah ini.

Tabel 3 Tingkat Retensi Pekerja Angkutan Kota 


\begin{tabular}{|c|c|c|c|}
\hline $\begin{array}{c}\text { Kode } \\
\text { Trayek }\end{array}$ & $\begin{array}{c}\text { Jumlah Pekerja } \\
\text { Tahun 2009 }\end{array}$ & $\begin{array}{c}\text { Jumlah Pekerja } \\
\text { Tahun 2019 }\end{array}$ & $\begin{array}{c}\text { Retensi } \\
\text { Pekerja }\end{array}$ \\
\hline 1 & 52 & 10 & $19 \%$ \\
\hline 2 & 118 & 25 & $21 \%$ \\
\hline 3 & 62 & 16 & $26 \%$ \\
\hline 5 & 57 & 15 & $26 \%$ \\
\hline 6 & 119 & 33 & $28 \%$ \\
\hline 7 & 62 & 27 & $44 \%$ \\
\hline 10 & 53 & 24 & $45 \%$ \\
\hline 27 & 32 & 18 & $56 \%$ \\
\hline \multicolumn{3}{|c|}{ Rata-rata } & $33 \%$ \\
\hline
\end{tabular}

Sumber: Hasil Analisis

Dari Tabel V.35 diatas dapat diketahui bahwa terjadi penurunan jumlah pekerja yang cukup signifikan, retensi pekerja rata-rata sebesar 33\%.

- Kesiapan Pekerja

Tolok ukur ini digunakan untuk mengetahui tingkat kecakapan pekerja dalam melaksanakan tugasnya, dalam hal tersebut sebagai dasar bahwa pekerja dipastikan pada usia yang sesuai juga memiliki kemampuan mengemudi yang baik maka tingkat kesiapan pekerja dinilai dari kepemilikan Surat Izin Mengemudi (SIM) A Umum. Berdasarkan hasil wawancara pengemudi yang dilakukan Tim PKL Kota Kupang pada tahun 2019 didapatkan data bahwa seluruh pengemudi armada angkutan kota di Kota Kupang pada tahun 2019 seluruhnya memiliki Surat Izin Mengemudi (SIM) A Umum.

\section{Gambaran Kinerja Pelayanan Angkutan Perkotaan dengan Menggunakan Balanced Scorecard}

Setelah melakukan analisa atas kinerja masing-masing perspektif maka langkah selanjutnya adalah melakukan penilaian kinerja secara keseluruhan pada Angkutan Kota di Kota Kupang.

a. Memberi penilaian atas kinerja tolok ukur

Langkah pertama dari penilaian kinerja angkutan kota adalah dengan memberikan nilai pada masing-masing tolok ukur yang ada di setiap perspektif yang menunjukkan penilaian kinerja tolok ukur. Nilai yang diberikan merupakan hasil kesepakatan dengan pihak regulator dalam hal ini adalah Dinas Perhubungan Kota Kupang. Nilai yang diberikan merupakan pencapaian tolok ukur dari masing- masing perspektif dibandingkan dengan target yang telah ditetapkan. Skala penilaian hasil kinerja dapat dilihat pada Tabel 4 dibawah ini.

Tabel 4 Skala Penilaian Hasil Kinerja Tolok Ukur 


\begin{tabular}{|c|c|l|}
\hline Nilai & Hasil & \multicolumn{1}{|c|}{ Deskripsi } \\
\hline 1 & Kurang Sekali & $\begin{array}{l}\text { Realisasi pencapaian kurang dari } \\
50 \% \text { dari target yang ditetapkan }\end{array}$ \\
\hline 2 & Kurang & $\begin{array}{l}\text { Realisasi pencapaian 50-69\% dari } \\
\text { target yang ditetapkan }\end{array}$ \\
\hline 3 & Cukup & $\begin{array}{l}\text { Realisasi pencapaian 70-89\% dari } \\
\text { target yang ditetapkan }\end{array}$ \\
\hline 4 & Baik & $\begin{array}{l}\text { Realisasi pencapaian 90-100\% } \\
\text { dari target yang ditetapkan }\end{array}$ \\
\hline 5 & Baik Sekali & $\begin{array}{l}\text { Realisasi pencapaian lebih dari } \\
100 \% \text { dari target yang ditetapkan }\end{array}$ \\
\hline
\end{tabular}

b. Menghitung nilai masing-masing perspektif

Nilai perspektif adalah nilai rata-rata tolok ukur untuk masing- masing perspektif

c. Menghitung nilai masing-masing perspektif

Bobot (weight) perspektif memiliki range 0,0 (tidak penting) sampai 1,0 (sangat penting). Bobot tersebut mengindikasikan tingkat kepentingan relatif perspektif terhadap keberhasilan operator dalam menjalankan usahanya. Jumlah bobot seluruh perspektif harus sama dengan 1,0. Bobot yang diberikan merupakan asumsi yang didasarkan atas kepentingan tiap perspektif yang kemudian disetujui oleh regulator yaitu pihak Dinas Perhubungan Kota Kupang. Hasil kesepakatan tersebut didapatkan nilai bobot tiap perspektif, yaitu sebesar:

- Bobot perspektif pelanggan $=0,28$

- Bobot perspektif keuangan $=0,24$

- Bobot perspektif proses bisnis internal =0,24

- Bobot perspektif pertumbuhan dan pembelajaran $=0,24$

d. Penentuan nilai kinerja keseluruhan

Langkah selanjutnya adalah menghitung nilai kinerja yang diperoleh dari perkalian antara nilai perspektif dengan bobot perspektif. Selanjutnya adalah menghitung nilai kinerja keseluruhan yang merupakan jumlah total nilai kinerja perspektif yang menunjukkan kinerja angkutan kota secara menyeluruh. Kriteria penilaian kinerja dapat dilihat pada Tabel 5 dibawah ini.

Tabel 5 Kriteria Penilaian Kinerja

\begin{tabular}{|c|c|c|}
\hline Nilai Kinerja & Prestasi & Kriteria \\
\hline $1.00-1.84$ & KS & Kurang Sekali \\
\hline $1.85-2.69$ & $\mathrm{~K}$ & Kurang \\
\hline $2.70-3.54$ & $\mathrm{C}$ & Cukup \\
\hline $3.55-4.39$ & $\mathrm{~B}$ & Baik \\
\hline $4.40-5.00$ & $\mathrm{BS}$ & Baik Sekali \\
\hline
\end{tabular}

Sumber: Sistem manajemen kinerja terintegrasi Balanced Scorecard dengan six sigma untuk organisasi dan pemerintah, 2006

e. Kinerja Keseluruhan Angkutan Kota 
Kinerja pelayanan angkutan kota di Kota Kupang berdasarkan metode Balanced Scorecard dapat dilihat pada Tabel 6 dibawah ini.

\section{Tabel 6 Tabel Pengukuran Kinerja Angkutan Kota}

\begin{tabular}{|c|c|c|c|c|c|c|c|}
\hline $\begin{array}{l}N \\
0\end{array}$ & $\begin{array}{l}\text { Tolak Ukur } \\
\text { Perspektif }\end{array}$ & $\begin{array}{l}\text { Targe } \\
\mathbf{t}\end{array}$ & $\begin{array}{l}\text { Realisas } \\
\text { i }\end{array}$ & $\begin{array}{l}\text { Nilai Tolok } \\
\text { Ukur }\end{array}$ & $\begin{array}{l}\text { Nilai } \\
\text { Perspektif }\end{array}$ & $\begin{array}{l}\text { Bobo } \\
t\end{array}$ & $\begin{array}{l}\text { Nilai } \\
\text { Kinerja }\end{array}$ \\
\hline $\begin{array}{l}(1 \\
)\end{array}$ & (2) & (3) & (4) & (5) & $(6)=$ mean $(5)$ & (7) & $(8)=(7 \times 6)$ \\
\hline \multicolumn{8}{|c|}{ Perspektif Pelanggan } \\
\hline 1 & Retensi Pelanggan & $100 \%$ & $25,76 \%$ & 1 & \multirow{3}{*}{2,66} & \multirow{3}{*}{0,28} & \multirow{3}{*}{0,74} \\
\hline 2 & Tingkat Komplain & $0 \%$ & $2,57 \%$ & 4 & & & \\
\hline 3 & $\begin{array}{l}\text { Kepuasan } \\
\text { Perlanggan }\end{array}$ & & & 2,98 & & & \\
\hline \multicolumn{8}{|c|}{ Perspektif Keuangan } \\
\hline 1 & Tingkat Laba & $100 \%$ & $8 \%$ & 1 & 1 & 0,24 & 0,24 \\
\hline \multicolumn{8}{|c|}{ Perspektif Proses Bisnis Internal } \\
\hline 1 & Utilitas Armada & $100 \%$ & $68,18 \%$ & 2 & \multirow{2}{*}{3} & \multirow{2}{*}{0,24} & \multirow{2}{*}{0,72} \\
\hline 2 & Kecelakaan Armada & 0 & $0,08 \%$ & 4 & & & \\
\hline \multicolumn{8}{|c|}{ Perspektif Pertumbuhan dan Pembelajaran } \\
\hline 1 & Retensi Pekerja & $100 \%$ & $33 \%$ & 1 & \multirow{2}{*}{2,5} & \multirow{2}{*}{0,24} & \multirow{2}{*}{0,60} \\
\hline 2 & Kesiapan Pekerja & $100 \%$ & $100 \%$ & 4 & & & \\
\hline
\end{tabular}

Dari Tabel 6 diatas dapat diketahui bahwa kinerja keseluruhan dari Angkutan Kota di Kota Kupang memiliki nilai 2,30 yang berada pada kriteria "Kurang". Kinerja keseluruhan menunjukkan nilai yang baik dari faktor kecelakaan armada dari perspektif proses bisnis internal, yang menunjukkan minimnya kejadian kecelakaan lalu lintas yang melibatkan angkutan kota, faktor kesiapan pekerja angkutan kota juga memiliki nilai yang baik dilihat dari kepemilikan Surat Izin Mengemudi (SIM) pada pengemudi angkutan kota, serta tingkat komplain pengguna memiliki nilai yang baik namun perlu digarisbawahi masyarakat belum memiliki platform resmi untuk mengajukan keluhan serta saran bagi angkutan kota. Sebaliknya untuk pengembangan kualitas pelayanan angkutan kota, maka perlu memperhatikan faktor-faktor yang memiliki nilai yang kurang baik seperti finansial operator, retensi pelanggan, kepuasan pelanggan, utilitas armada, serta retensi pekerja.

\section{Perbandingan Kinerja Pelayanan Kondisi Eksisting Dengan Hasil Usulan Kinerja Pelayanan Angkutan Kota di Kota Kupang}

Kinerja pelayanan angkutan umum jaringan trayek usulan dapat dibandingkan dengan kondisi jaringan trayek eksisting, dimana indikator pelayanan yang dinilai antara lain frekuensi rata- rata, headway rata-rata, waktu Perjalanan rata-rata, kecepatan rata-rata, dan faktor muat ratarata. Dengan mengevaluasi jumlah trayek dan merasionalkan jumlah armada, maka kinerja pelayanan angkutan kota dapat diperbaiki. Frekuensi angkutan umum eksisting rata-rata sebesar 8 kendaraan/jam dapat diperbaiki menjadi 12 kendaraan/jam. Waktu antar kendaraan juga dapat 
ditingkatkan dari kondisi eksisting sebesar 9 menit menjadi 6,5 menit pada kinerja pelayanan usulan. Dan untuk waktu perjalanan rata-rata eksisting sebesar 46 menit menjadi 21 menit.

Penetapan usulan peningkatan kinerja pelayanan diharapkan memberikan dampak baik terhadap jalannya pengoperasian angkutan kota di Kota Kupang terutama terhadap demand perjalanan menggunakan angkutan kota yang merupakan permasalahan utama. Oleh karena itu, untuk melihat peningkatan jumlah perjalanan masyarakat menggunakan angkutan kota setelah diterapkannya usulan peningkatan pelayanan diperlukan analisis forecasting jumlah perjalanan tahun-tahun berikutnya menggunakan rumus compounding factor dan persamaan regresi untuk melihat persebaran perjalanan di setiap zona. Berikut adalah jumlah perjalanan tahun 2019, 2020, 2021, 2022. 2023, 2024, 2025, 2026, 2027, 2028, dan tahun 2029 yang dibagi menjadi perjalanan menggunakan motor, mobil, dan MPU apabila diterapkannya usulan peningkatan kinerja pelayanan angkutan kota di Kota Kupang.

Tabel 7 Forecasting Jumlah Perjalanan Tanpa Upaya Peningkatan Kinerja Pelayanan Angkutan Kota

\begin{tabular}{|c|c|c|c|}
\hline \multirow{2}{*}{ Tahun } & \multicolumn{3}{|c|}{ Pemilihan Moda } \\
\cline { 2 - 4 } & Motor & Mobil & MPU \\
\hline 2019 & 783016 & 167567 & 35470 \\
\hline 2020 & 803439 & 171937 & 36395 \\
\hline 2021 & 829498 & 177514 & 37575 \\
\hline 2022 & 856804 & 183357 & 38812 \\
\hline 2023 & 885603 & 189520 & 40117 \\
\hline 2024 & 915863 & 195996 & 41488 \\
\hline 2025 & 947758 & 202822 & 42932 \\
\hline 2026 & 981423 & 210026 & 44457 \\
\hline 2027 & 1017009 & 217641 & 46069 \\
\hline 2028 & 1054683 & 225704 & 47776 \\
\hline 2029 & 1094627 & 234252 & 49585 \\
\hline
\end{tabular}

Sumber: Hasil analisis

Tabel 8 Forecasting Jumlah Perjalanan Dengan Diterapkannya Upaya Peningkatan Kinerja Pelayanan Angkutan Kota 


\begin{tabular}{|c|c|c|c|}
\hline \multirow{2}{*}{ Tahun } & \multicolumn{3}{|c|}{ Pemilihan Moda Setelah Perbaikan } \\
\cline { 2 - 4 } & Motor & Mobil & MPU \\
\hline 2019 & 769684 & 164523 & 51846 \\
\hline 2020 & 789759 & 168814 & 53198 \\
\hline 2021 & 815374 & 174290 & 54924 \\
\hline 2022 & 842215 & 180027 & 56732 \\
\hline 2023 & 870523 & 186078 & 58639 \\
\hline 2024 & 900268 & 192436 & 60642 \\
\hline 2025 & 931620 & 199138 & 62754 \\
\hline 2026 & 964712 & 206211 & 64983 \\
\hline 2027 & 999692 & 213689 & 67339 \\
\hline 2028 & 1036724 & 221604 & 69834 \\
\hline 2029 & 1075988 & 229997 & 72479 \\
\hline
\end{tabular}

Sumber: Hasil analisis

Dari Tabel 7 dan Tabel 8 diatas dapat dilihat bahwa penerapan usulan peningkatan kinerja mampu mempengaruhi jumlah perjalanan menggunakan angkutan kota serta menekan penggunaan kendaraan pribadi. Persentase pemilihan moda juga berubah untuk moda angkutan jenis motor dari $77,95 \%$ menjadi $76,63 \%$, moda angkutan jenis mobil berubah dari $16,68 \%$ menjadi $16,38 \%$, dan untuk angkutan kota berubah dari 3,53\% menjadi 5,16\%.

\section{KESIMPULAN}

Waktu antar kendaraan terdapat beberapa trayek yang belum memenuhi standar yaitu trayek 1 dan trayek 27 pada jam sibuk. Trayek 1, trayek 3, dan trayek 27 diluar waktu sibuk. Pada aspek frekuensi, trayek 2 dan trayek 6 saja yang memenuhi standar untuk jam sibuk. Untuk waktu perjalanan seluruh trayek memenuhi standar yaitu dibawah 1,5 jam. Sedangkan untuk faktor muat dan kecepatan perjalanan seluruhnya belum memenuhi standar pelayanan. Hasil analisis kinerja angkutan kota di Kota Kupang dengan menggunakan metode Balanced Scorecard memberikan gambaran aspek angkutan kota yang bermasalah dari tiap perspektif yang dari segi nilai masuk kedalam prioritas perbaikan, yaitu: Retensi pelanggan pada perspektif pelanggan; Tingkat laba pada perspektif keuangan; Retensi pekerja pada perspektif pertumbuhan dan pembelajaran.

\section{DAFTAR PUSTAKA}

Peraturan Pemerintah Republik Indonesia Nomor 41 Tahun 1993 Tentang Angkutan Jalan. Pemerintah Pusat.

Keputusan Menteri Perhubungan No. 35 Tahun 2003 Tentang Penyelenggaraan Angkutan Orang Di Jalan Dengan Kendaraan Umum. Kementrian Perhubungan. Jakarta.

Surat Keputusan Jumlah Armada Angkutan Kota Tahun 2018.

Undang-undang Nomor 22 Tahun 2009 Tentang Lalu Lintas dan Angkutan Jalan.

Peraturan Gubernur Tentang Tarif Dasar Angkutan Penumpang, Tarif Angkutan Kota Dan Tarif Jarak Trayek Angkutan Antar Kota Dalam Provinsi (AKDP) Di Provinsi Nusa Tenggara Timur.

Peraturan Menteri Perhubungan Republik Indonesia No. PM 132 Tahun 2015 Tentang Penyelenggaraan Terminal Penumpang Angkutan Jalan. 
Huda, A. Z. (2013). Analisis Kinerja Dengan Pendekatan Balanced Scorecard. 6-10. Fakultas Ekonomi Dan Bisnis. Universitas Muhammadiyah Surakarta.

Angga, A. (2018). Perencanaan Bus Rapid Transit (BRT) Kabupaten Purworejo. D III Lalu Lintas Angkutan Jalan. Politeknik Transportasi Darat Indonesia-STTD.

Zulfa, A. R. (2013). Analisis Kinerja Transjakarta Busway Dalam Kerangka Balanced Scorecard. Fakultas Ekonomi. Universitas Indonesia.

Amanda Safira T. (2019). Analisis Peningkatan Pelayanan Angkutan Pedesaan Wilayah Perkotaan Purwokerto. D IV Transportasi Darat. Politeknik Transportasi Darat Indonesia-STTD.

Andriariza, Y. (2006). Pembuatan Aplikasi Untuk Perencanaan Trayek Angkutan Kota Di Kota Mojokerto. Fakultas Teknik Sipil dan Perencanaan. Institut Teknologi Sepuluh Nopember. Surabaya.

Saputra, A. T. (2018). Perencanaan Pengoperasian Angkutan Sekolah Di Kota Surakarta.. D IV Transportasi Darat. Politeknik Transportasi Darat Indonesia-STTD.

Dewi, A. I. T. (2009). Balanced Scorecard Sebagai Pengukur Kinerja Perusahaan. Fakultas Ekonomi. Universitas Jember.

Arikunto, S. (1997). Prosedur Penelitian: Suatu Pendekatan Praktek. Edisi Revisi IV. Jakarta: Rineka Cipta.

Arikunto, S. (2002). Metodologi Penelitian Suatu Pendekatan Proposal. Edisi Revisi. Jakarta: Rineka Cipta.

Badan Pusat Statistik. (2019). Kota Kupang Dalam Angka Tahun 2019.

Saputra, B. T. (2004). Analisis Kinerja Dinas Pertanian Kabupaten Bogor Dengan Konsep Kartu Nilai Berimbang. Fakultas Pertanian. Institut Pertanian Bogor.

Bambang Supomo \& Nur Indriantoro. (2002). Metodologi Penelitian Bisnis Cetakan Kedua. Yogyakarta: Penerbit BFEE UGM.

Putra, B. I. (2005). Analisis Pengukuran Kinerja Dengan Metode Balanced Score Card (BSC) Di CV MCH Sidoarjo. Teknik Industri. Universitas Muhammadiyah Sidoarjo.

Darmawanto, A. (2009). Analisis Balanced Scorecard Sebagai Alat Ukur Kinerja Pada PT Sepatu Asia. Fakultas Ekonomi. Universitas Gunadarma.

Gaspersz, V. (2005). Sistem Manajemen Kinerja Terintegrasi: Balanced Scorecard Dengan Six Stigma. Jakarta: Gramedia Pustaka Utama.

Ghozali, I. (2002). Aplikasi Analisis Multivariate dengan Program SPSS (4th ed.). Semarang: Badan Penerbit-UNDIP.

Hagi Parasianta, F. (2012). Analisis Kinerja Komprehensif Dengan Pendekatan Balanced Scorecard Pada Perusahaan Perdagangan Besar/Wholeseller. Fakultas Ekonomika dan Bisnis. Universitas Diponegoro. Semarang.

Hansen, Don. R. and Maryanne M. Mowen. (2004). Akuntansi Manajemen, Buku 1.Edisi 7. Jakarta: Salemba Empat.

Hernanto, Y. (2009). Pengukuran Kinerja Dengan Pendekatan Balanced Scorecard Pada PT Bank Syariah Mandiri Cabang Bogor. Fakultas Ekonomi dan Manajemen. Institut Pertanian Bogor.

Ilham, Y. (2014). Efektivitas Kinerja Dengan Konsep Balanced Scorecard Dalam Perspektif Pelanggan Pada BMT Al-Fath IKMI Di Tangerang Selatan. Fakultas Ilmu Dakwah Dan Ilmu Komunikasi. UIN Syarif Hidayatullah. 
Kamalia, Cornelius, \& Anisa. (2015). Analisis Balanced Scorecard Sebagai Alat Pengukuran Kinerja Pada CV Yamaha Sinar Utama Hidayatullah Samarinda. Vol. 12 No. 2. 177179.

Kaplan, Robert S. \& David P. Norton. (1992). The Balanced Scorecard: Measures That Drive Performance. Harvard Business Review. Massachussetts.

Kaplan, Robert S. \& David P. Norton. (2000). Balanced Scorecard: Menerapkan Strategi Menjadi Aksi. Terjemahan oleh Peter R. Yosi Pasla dari Balanced Scorecard: Translating Strategy Into Action (1996). Jakarta: Erlangga.

Kusuma, K. I. W. (2019). Penerapan Metode Quality Function Deployment Dalam Upaya Peningkatan Kinerja Pelayanan Angkutan Umum Di Kota Cirebon. D IV Transportasi Darat. Politeknik Transportasi Darat Indonesia-STTD.

Luis, S. \& Biromo, P. A. (2007). Step by Step in Cascading Balanced Scorecard to Functional Scorecards. Jakarta: PT. Gramedia Pustaka Utama.

Mulyadi. (1997). Akuntansi Manajemen: Konsep, Manfaat dan Rekayasa. Edisi 8. Yogyakarta: STIE-YKPN.

Mulyadi. (2001). Balanced Scorecard: Alat Manajemen Kontemporer Untuk Pelipatgandaan Kinerja Keuangan Perusahaan. Edisi Pertama. Jakarta: Salemba Empat.

Mutasowifin, A. (2002). Penerapan Balanced Scorecard Sebagai Tolok Ukur Penilaian Pada Badan Usaha Berbentuk Koperasi. Vol. 1 No. 3. 245-264.

Pramadhany, W. (2011). Penerapan Metode Balanced Scorecard Sebagai Tolok Ukur Penilaian Kinerja Pada Organisasi Nirlaba. Fakultas Ekonomi. Universitas Diponegoro. Semarang.

Pusdika, H. (2016). Pengaruh Penerapan Balanced Scorecard Terhadap Kinerja Manajemen PT. Bank Rakyat Indonesia, TBK. Fakultas Ekonomi dan Bisnis. Universitas Islam Negeri Syarif Hidayatullah. Jakarta.

Seprinal. (2005). Balanced Scorecard Sebagai Pengukuran Kinerja Manajemen. Fakultas Ekonomi. Universitas Sumatera Utara.

Sugiyono. (2012). Metode Penelitian Kuantitatif Kualitatif dan R\&D. Bandung: Alfabeta.

Tim PKL Kota Kupang, (2009). Laporan Umum Praktik Kerja Lapangan Kota Kupang Tahun 2009.

Tim PKL Kota Kupang, (2019). Laporan Umum Praktik Kerja Lapangan Kota Kupang Tahun 2019.

Umar, H. 2001. Riset Pemasaran dan Perilaku Konsumen. Jakarta: PT. Gramedia Pustaka Utama. Warpani, S. (1990). Merencanakan Sistem Perangkutan. Bandung.

Darma. W. R. (2009). Pengukuran Kinerja Program Raskin Dengan Metode Balanced Scorecard Di Perum Bulog DIVRE SUMUT. Fakultas Teknik. Universitas Sumatera Utara. Medan.

Laksmita. V. A. (2011). Analisis Pengukuran Kinerja Perusahaan Dengan Metode Balanced Scorecard. Fakultas Ekonomi. Universitas Diponegoro.

Veronica P. A. (2015). Evaluasi Kinerja Berdasarkan Balanced Scorecard. Fakultas Ekonomi. Universitas Sanata Dharma.

Yovianda, A. (2017). Analisis Kinerja Rumah Sakit Dengan Pendekatan Balanced Scorecard. Fakultas Ekonomi. Universitas Andalas Padang.

Zakky. (2005). Fenomena Angkutan Desa-Kota di Kabupaten Boyolali. UNDIP.

Zudia, M. (2010). Analisis Penilaian Kinerja Organisasi Dengan Menggunakan Konsep Balanced Scorecard Pada PT Bank Jateng Semarang. Fakultas Ekonomi. Universitas Diponegoro. 